\title{
THE ALTARPIECE OF THE CHAPEL OF GUARENAS AND THE ALTARPIECES OF THE SIDE CHAPELS OF THE CHURCH OF SAN JACINTO DE CARACAS
}

\author{
MARIOLLY DÁVILA ${ }^{1} \&$ ORLANDO MARÍN ${ }^{2}$ \\ ${ }^{1}$ Universidad del Norte, Colombia \\ ${ }^{2}$ Universidad Simón Bolívar, Venezuela
}

\begin{abstract}
The following paper presents an approach to the possible original location of an altarpiece that, according to tradition, belonged to the Church of San Jacinto convent in Caracas in the XVIII century, in order to document and register Venezuelan cultural heritage and to continue the process (initiated in 2011 as part of a previous investigation) of virtual restitution of architectural assets already disappeared through the digital techniques currently available. The altarpiece, located since the XIX century, after the demolition of the convent, in the Chapel of La Candelaria in Guarenas - a town located in the outskirts of the capital - is made up of the fragments of three other ancient altarpieces, the greater of which must have been located in one of the aisles of the disappeared Caracas temple. The proposed methodology studies the geometry and shape of the piece to establish hypotheses regarding its initial location within the virtual space of the Chapel of the Rosary in the XVIII century Church of San Jacinto. Then, after reviewing perspective and digital techniques such as Augmented Reality, which allow us "in situ" verification, this process is completed with the bibliographical revision that confirms its relation with other altarpieces.
\end{abstract}

Keywords: altarpiece, heritage, Augmented Reality, San Jacinto de Caracas Convent.

\section{INTRODUCTION}

Following his last will (on June 6th, 1776) master carver Gregorio de León Quintana, who dressed in the habit of third of Santo Domingo, whose brotherhood he belonged, was buried in the Church of the convent of San Jacinto [1]; nevertheless, his wish for eternal rest in one of the oldest temples of the city - the Convent was already close to 170 years old - would be truncated in 1874 when the Venezuelan government decided to demolish the whole area, previously expropriated in 1837 , to incorporate its surface to the area of the main city marketplace [2].

The sacred character of the convent was no guarantee for the property's permanence in time. However, many of its movable goods would be relocated to other religious buildings. Such is the case of the Altarpiece, carved by Master León Quintana himself and his brother Juan Francisco around 1740, which came to be installed (although with mutilations) in the presbytery of the parish church of the town of San Mateo, more than 400 kilometers away [3].

As part of a previous research [4], a virtual reconstruction of the Church of the convent of San Jacinto was made; it was based on the hypothesis of the relationship between the space and the Altarpiece, and the dynamics that conditioned each other mutually; taking into account the known characteristics of the Altarpiece itself. The present work seeks to complement this exploration by incorporating data from the altarpiece of the Chapel of La Candelaria in the town of Guarenas, located 30 kilometers to the East of Caracas, an altarpiece that by its formal characteristics was presumed to belong to a church in Caracas [3] but that, according to tradition [5], came specifically from the church of San Jacinto 
(Fig. 1). The objective is to corroborate this by establishing the original location of this altarpiece in the spaces of the disappeared church by means of graphical techniques of comparative geometric analysis.

The first phase of the methodology consisted in collecting the metric and photographic information through the survey of the altarpiece of the Chapel of the Candelaria. This procedure corroborated an initial assumption [3]: that this altarpiece was the result of the integration of several pieces belonging to other altarpieces: one partially trimmed (which we call Altarpiece A) installed to continue with the concept of finishing the processional axis of the nave as a focal point of the scene, supported on fragments of other altarpieces also cut and recombined in a new composition (parts E, G, K and N on the one hand, parts B and I on the other) (Fig. 2).

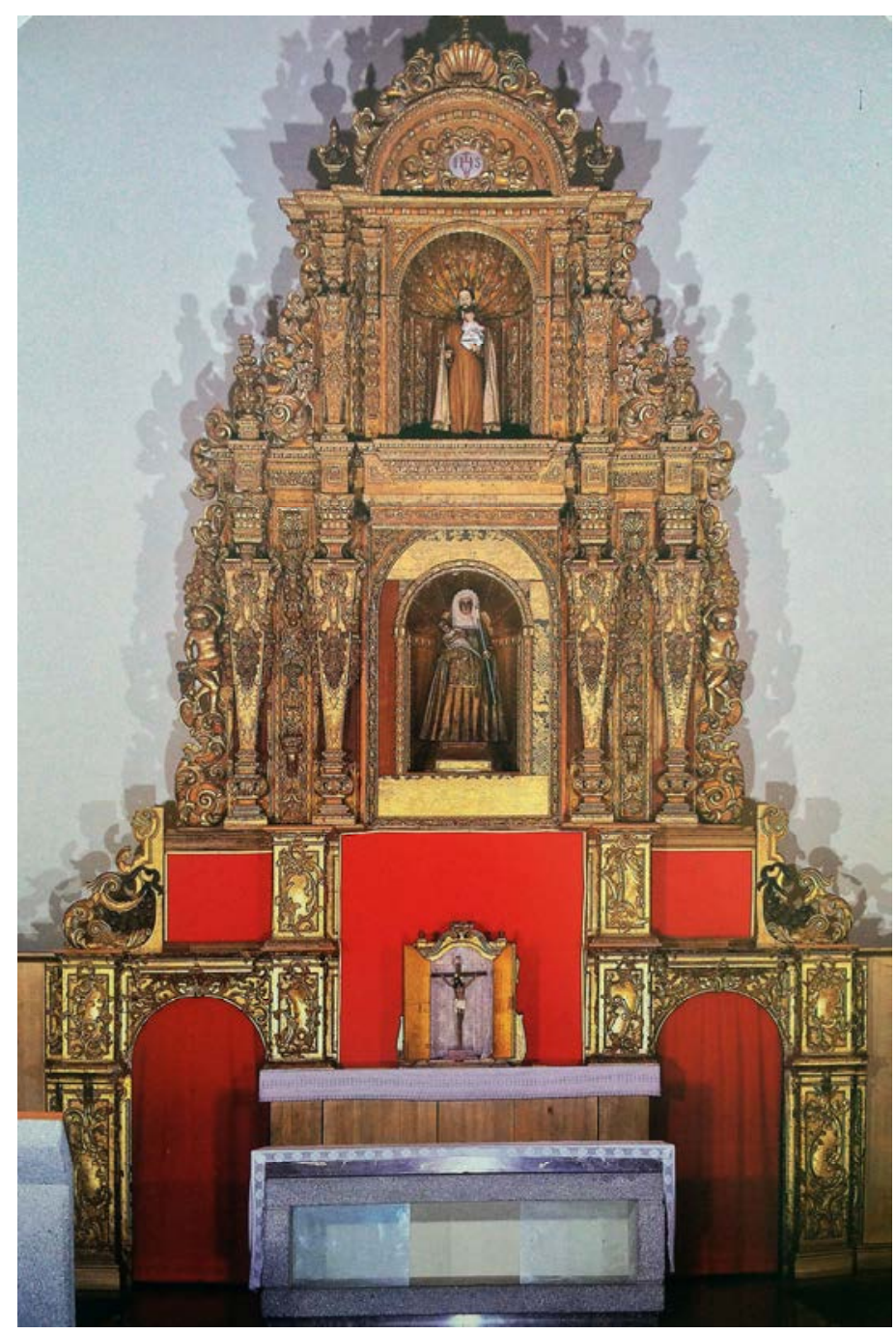

Figure 1: Altarpiece of the Chapel of La Candelaria in Guarenas. (Source: own elaboration, MDC, 2016.) 


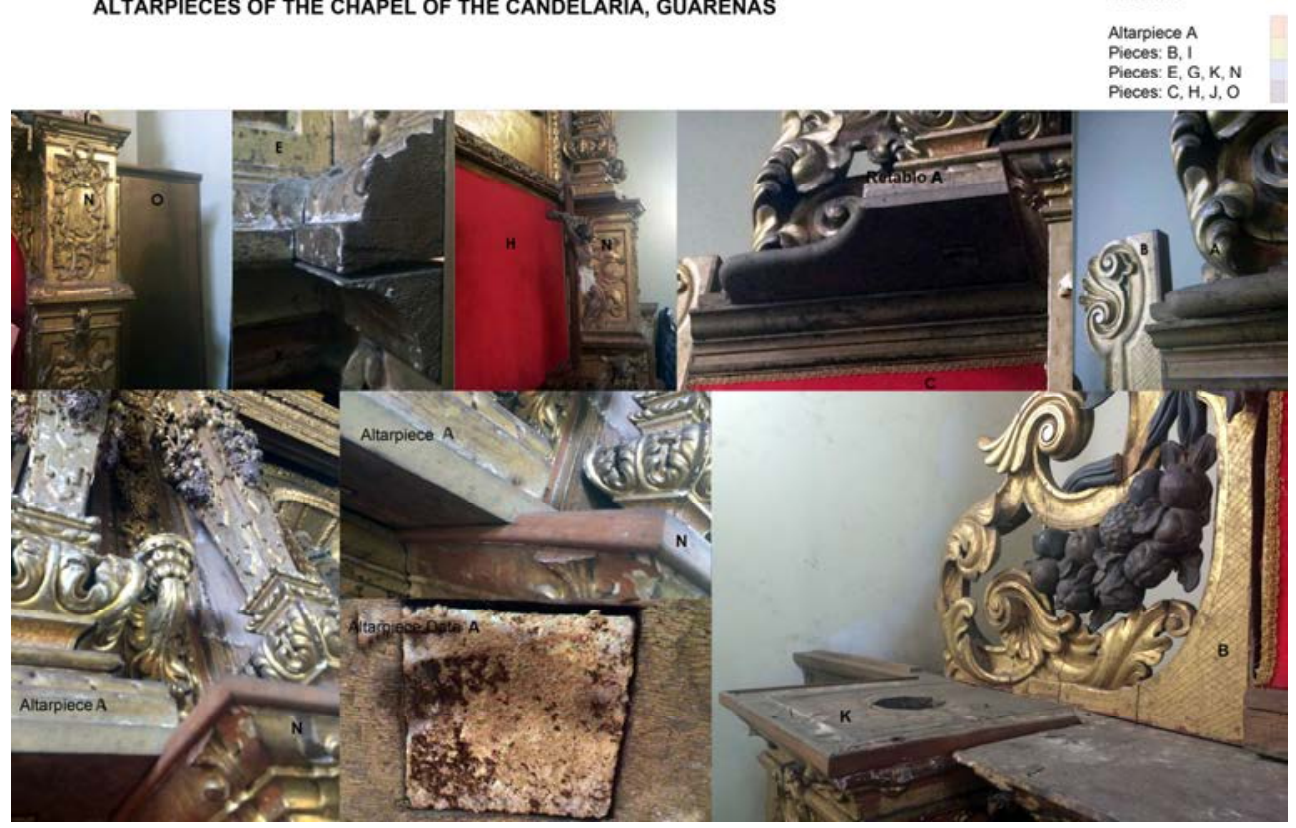

Figure 2: Details of the altarpiece of the Chapel of La Candelaria. (Source: own elaboration, MDC, 2016.)

Then the geometry of all the components and a reorganization of the work were redone under compositional considerations were to locate Altarpiece A spatially in the virtual model of the Church of San Jacinto in Caracas. Once fitted and placed the Altarpiece A on one of the aisles, a bibliographic study helped establish stylistic relations, authoring and complement their relationships with the space of the Church of San Jacinto.

\section{SPATIAL LOCATION ACCORDING TO 2D AND 3D DRAWINGS:}

We begin with the planimetrical location of Altarpiece A within the ecclesiastical space of the Church of San Jacinto of the XVIII century, given the fact that when people talk about the Altarpiece of the Chapel of the Candelaria they refer to the altarpiece itself and not to the pieces that support it.

As we pointed out above, we take as a given that the altarpiece belonged to one of the aisles; its dimensions, $3.15 \mathrm{~m}$ wide and $3.95 \mathrm{~m}$ in height, are extended considering the disappeared predella, completing the $5.00-6.50 \mathrm{~m}$ wide and $6.00-11.00 \mathrm{~m}$ in height, which are also the proportions of the lateral chapels in width and height, according to the study of other Venezuelan colonial churches [4].

We know that the chapels of the Church of San Jacinto (of the Holy Jesus, of the Virgin of the Rosary and of the Third Order) had the same dimensions of width: both are approx. $5.33 \mathrm{~m}$ long, except the Chapel of the Virgin of the Rosary which makes approx. $11.15 \mathrm{~m}$. The altarpieces that are found along the aisles are altars of greater or smaller proportions, for that reason we discard this possibility.

In the Chapel of the Holy Jesus, located on the nave of the gospel, was the altarpiece of the Sweet Name of Jesus. Its dimensions should be around $5.33 \mathrm{~m}$ wide, since it did not have 
communication doors with a sacristy and its geometry should adapt to the chapel, following the space-altarpiece relationship. This eliminates the possibility that the Altarpiece A being so narrow, had been designed for this space (Fig. 3).

The Chapel of the Virgin of the Rosary, in the nave of the epistle, besides allowing the reception by its dimensions of Altarpiece A, it also needed the placement of two lateral doors of access to its sacristy; this makes it narrower and, therefore, of lower height, maintaining its ratio 2:3.2. There is also a piece of information that needs to be revised: the altarpiece built by the León Quintana brothers between 1738 and 1740 “... with the elevation to raise and lower the Holy image of Our Lady", contracted by the Brotherhood of El Rosario, probably had to be placed in this Chapel and not in the Greater Altar, which relates it more strongly to the altarpiece of Guarenas and not to that of San Mateo.

In the Chapel of the Thirds, the possible dimension of an altarpiece (like the one elaborated by Leon Quintana in 1750) at its base is of $2.75 \mathrm{~m}$, that is to say, it would be more that of the altarpiece found in Guarenas; therefore, the Altarpiece A could not belong to this space.

\section{PERSPECTIVE VERIFICATION AND AUGMENTED REALITY}

For the confirmation of the maximum height of the altarpiece, we propose to superimpose in a longitudinal section of the Church the different angles of vision and in perspective through a verification in Augmented Reality. It is observed that $\mathrm{n}$ the longitudinal section, the height proposal of the altarpiece is justified. The altarpiece should measure about $7.40 \mathrm{~m}$ if it occupies the $5.33 \mathrm{~m}$ width in the chapel, with a viewing angle of $60^{\circ}$. As the altarpiece is smaller at its base, to save the golden ratio of the format 2:3, 2, it reduces its height (Figs 3 and 4).

SECTIONS SAN JACINTO CHURCH XVII CENTURY, CARACAS.

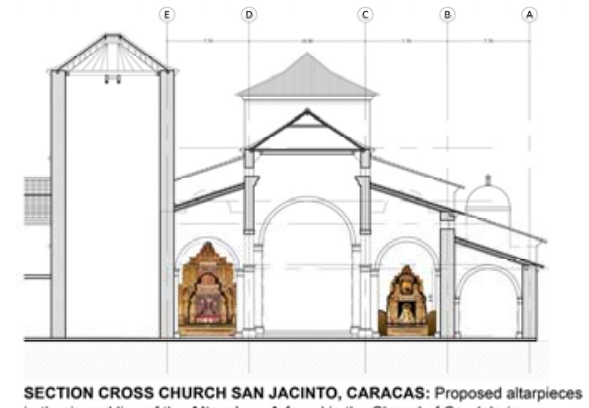

in thesis and line of the Altarpiece $A$ found in the Chapel of Candelaria.

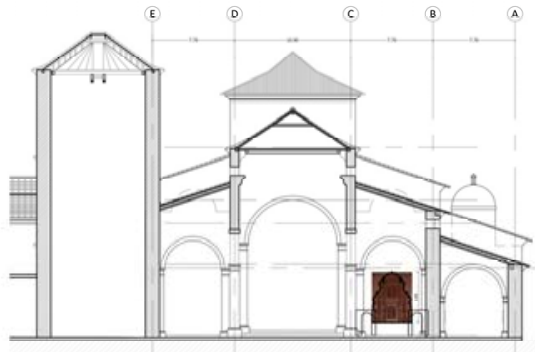

SECTION CROSS CHURCH SAN JACINTO, CARACAS Altarpiece A found in the Chapel of the Candelaria.

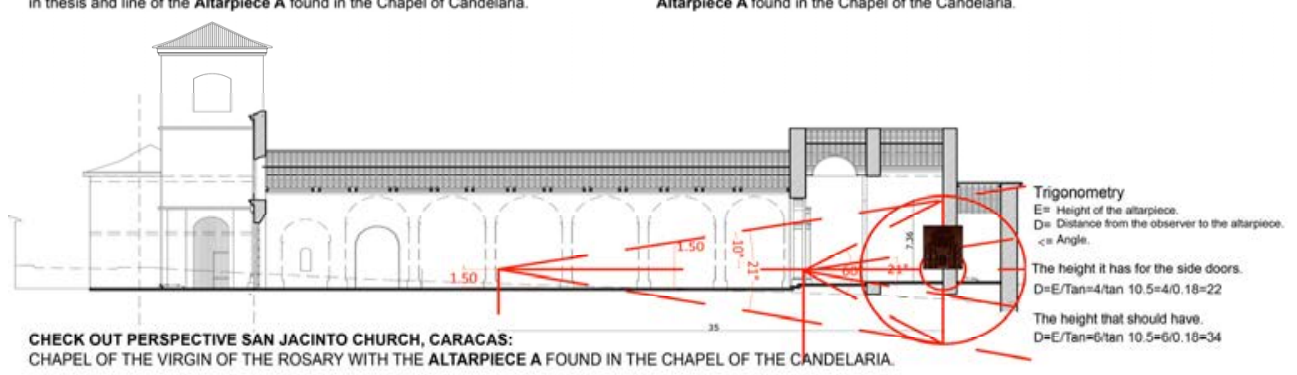

Figure 3: Sections of the Church of San Jacinto according to Virtual Reconstruction. (Source: own elaboration, MDC, 2016.) 


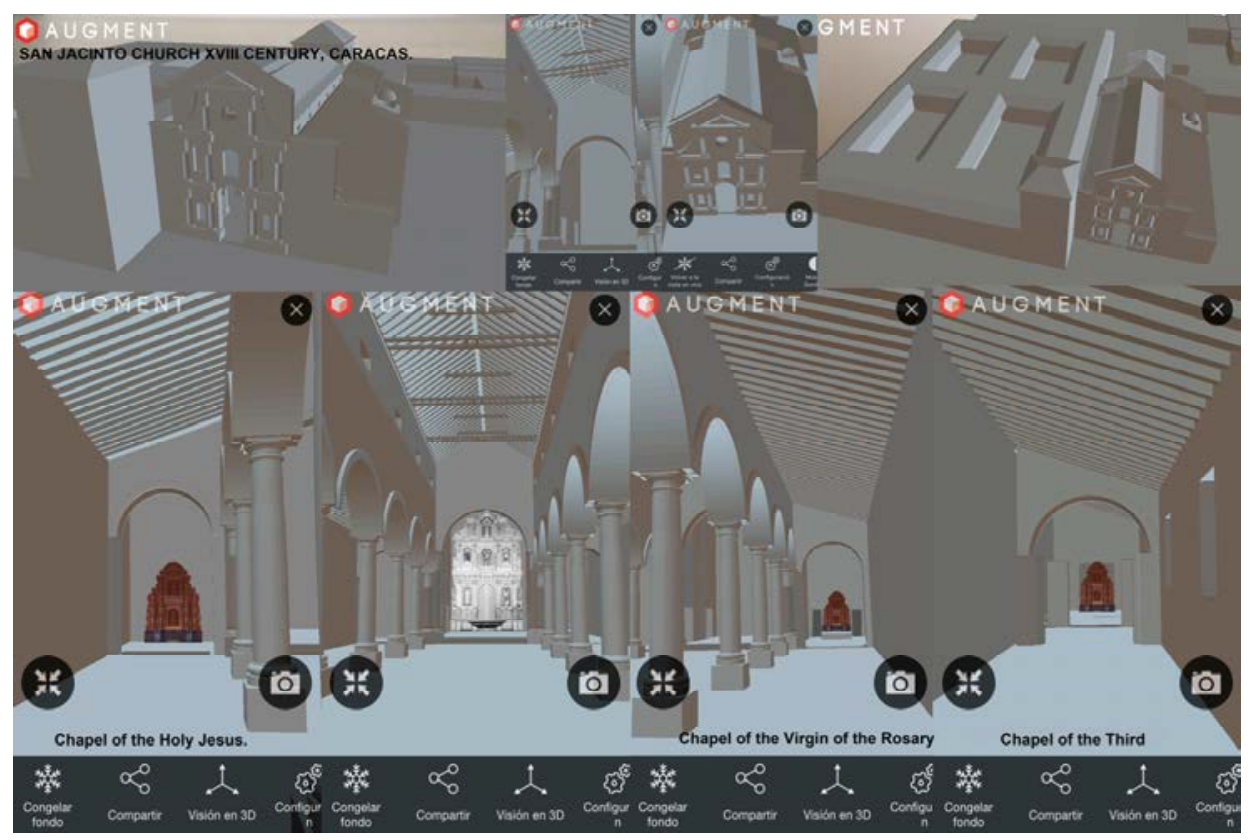

Figure 4: Augmented Reality test in church of San Jacinto according to Virtual Reconstruction. (Source: own elaboration, MDC, 2016).

\section{GEOMETRY OF THE ALTARPIECES OF THE AISLES}

The geometric analysis of La Candelaria Altarpiece shows an evident proportional difference between the base and the rest of the altarpiece. It is observed that the set consists of smaller pieces, such as borders, and the predella with side doors arranged in the lower part, and others of greater scale, such as the altarpiece itself, mutilated and with a panel, two bodies and a pinnacle, whose structural axes offer no continuity solution with those of the base. All the pieces are made with the same techniques and are of bitter cedar wood covered with gold leaf (Figs 5 and 6).

From the analysis, the following considerations emerge:

- Altarpiece A: Located in the center of the scene, consists of two bodies and a pinnacle as finish with double estipites support. The base, where the pedestal, stand, or predella was, was mutilated. The first body has as central figure the Virgin of La Candelaria and the second shows Jesus. The altarpiece is $3.15 \mathrm{~m}$ wide and $3.95 \mathrm{~m}$ high.

- Pieces B and I: Located on the sides of pieces $\mathrm{C}$ and H, on the predella where the Altarpiece rests. The edges usually top or complement the altarpieces on the lateral parts of the development of the bodies and the pinnacle. By their design and proportion they were part of a larger altarpiece from which they were cut. It is $60 \mathrm{~cm}$ wide by $75 \mathrm{~cm}$ high.

- Parts C, H: Located on the predella between parts B, E and G, I; are filler pieces that form part of some other altarpiece because of the frames they contain. They are $60 \mathrm{~cm}$ wide by $60 \mathrm{~cm}$ high.

- Pieces E, G: located on the predella as supporting pillars of the Altarpiece A. They are pieces that, due to their geometrical characteristics, are part of a pedestal, stand, or predella of a larger altarpiece that should directly support the estipites. They are $30 \mathrm{~cm}$ wide by $60 \mathrm{~cm}$ high. 
ALTARPIECES OF THE CHAPEL OF THE CANDELARIA, GUARENAS
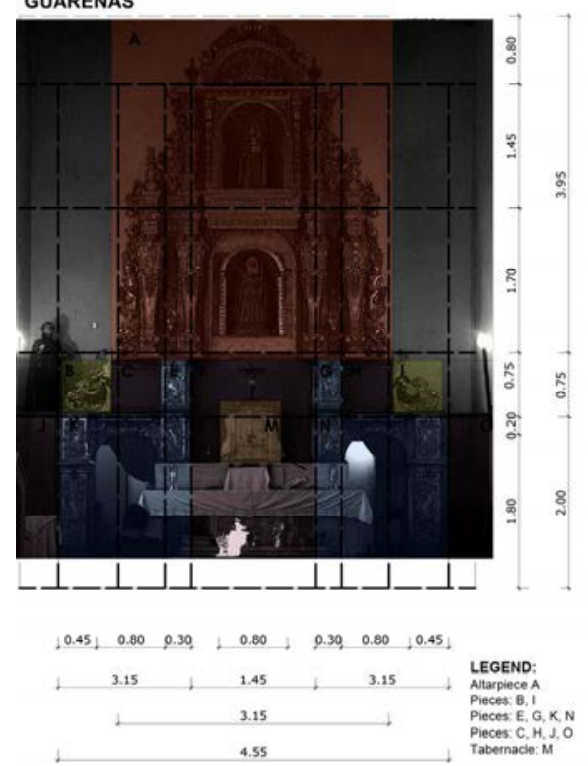

COMPOSITION OF THE ALTARPIECE OF THE CHAPEL OF CANDELARIA.

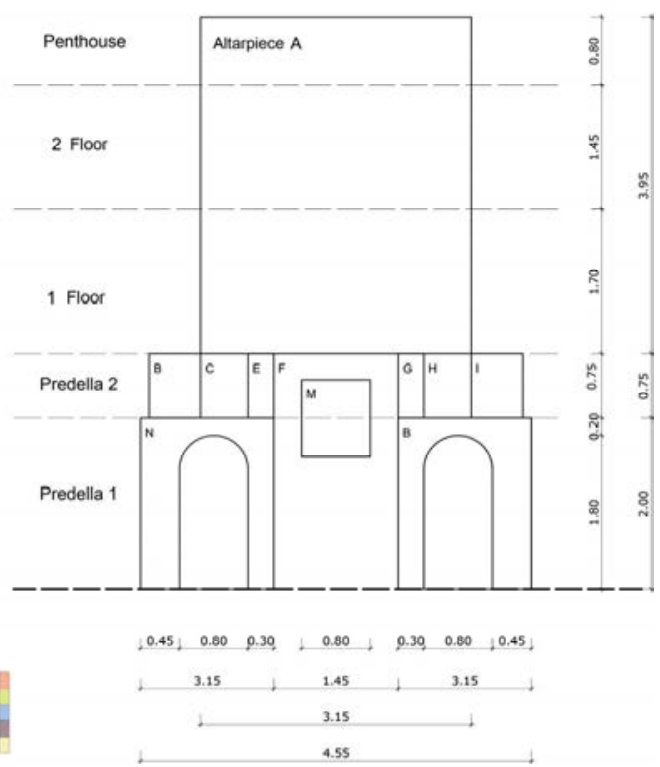

Figure 5: Layout of the altarpiece of La Candelaria. (Source: own elaboration, MDC, 2016.)

GEOMETRY OF THE ALTARPIECE OF THE CHAPEL OF THE CANDELARIA
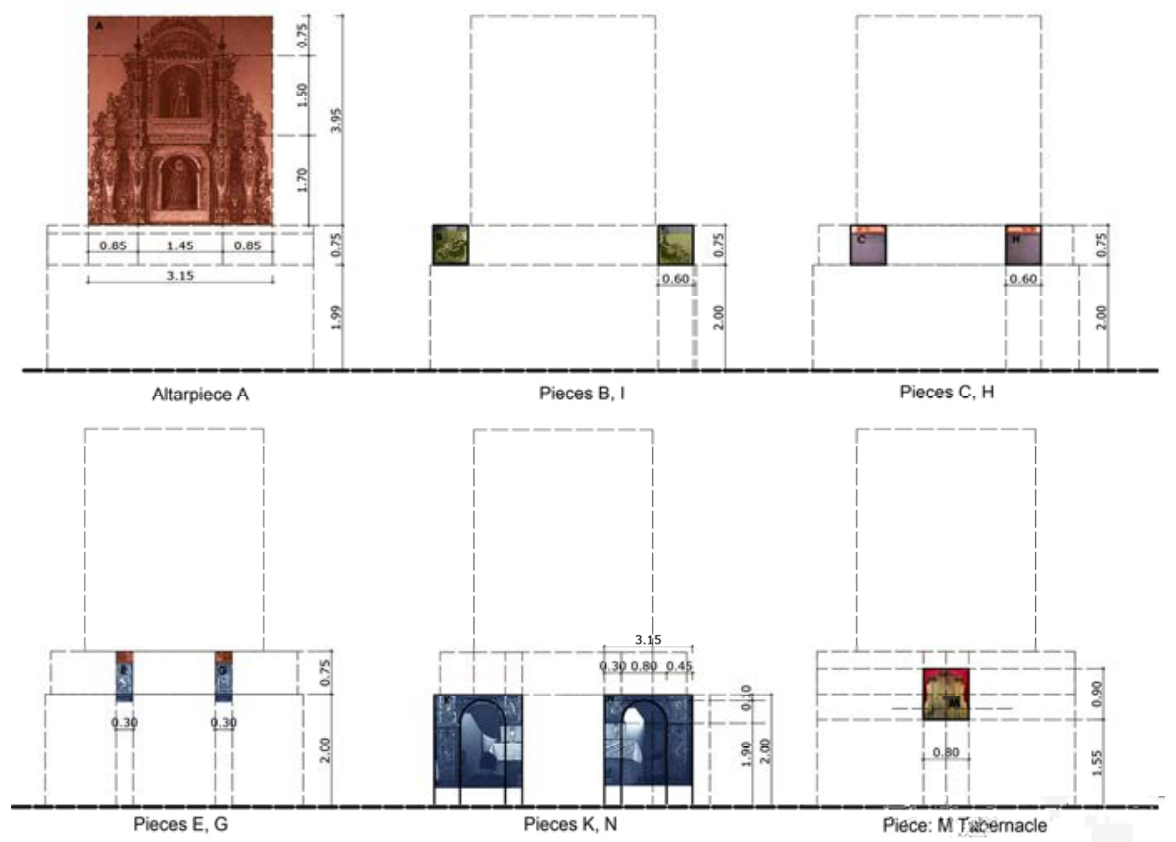

Figure 6: Geometry of the altarpiece of La Candelaria. (Source: own elaboration, $M D C, 2016$. 
- Parts K, N: Located on the stand, make structural support together with the $\mathrm{E}$ and $\mathrm{G}$ pieces of the predella. They are $3.15 \mathrm{~m}$ wide by $2 \mathrm{~m}$ in height. Together, it is part of the space that contained the side doors of a larger altarpiece.

- Tabernacle M: Located on the altar of the church. It is $80 \mathrm{~cm}$ wide by $90 \mathrm{~cm}$ high.

\section{RECOMPOSITION OR STRUCTURE}

After the metric survey the pieces were grouped by their geometry and their proportions resulting in three groups. The first one conformed by the Altarpiece A, with proportions appropriate for one of the aisles of the old Church of the Convent of San Jacinto. The second, made up of pieces $\mathrm{E}, \mathrm{G}, \mathrm{K}$ and $\mathrm{N}$ that constitutes the structural base, the doors and the predella. In the third group, we find decorative pieces B and I. Finally, the fourth group, constituted by the piece of the Tabernacle, which does not form a direct part of the altarpiece but is within the compositional scene.

In fact, the first group, conformed by Altarpiece A, confirms the previous work of virtual reconstruction of the Church of San Jacinto [4], which identifies it by its dimensions with some of the altarpieces of its aisles. Also, it is an incomplete altarpiece, which lacks its original base, so it's ideal height could be around $4.95 \mathrm{~m}$ and with a ratio close to the golden ratio of $2: 3.2(=1: 1.6) 18$. In this sense, the design of the altarpiece is resolved freely without being subjected to the geometric structure of the space of the chapel; this happens only when there are side doors, as can be seen in the Altarpiece of the Third Order of the Church of San Francisco in Caracas (Fig. 7).
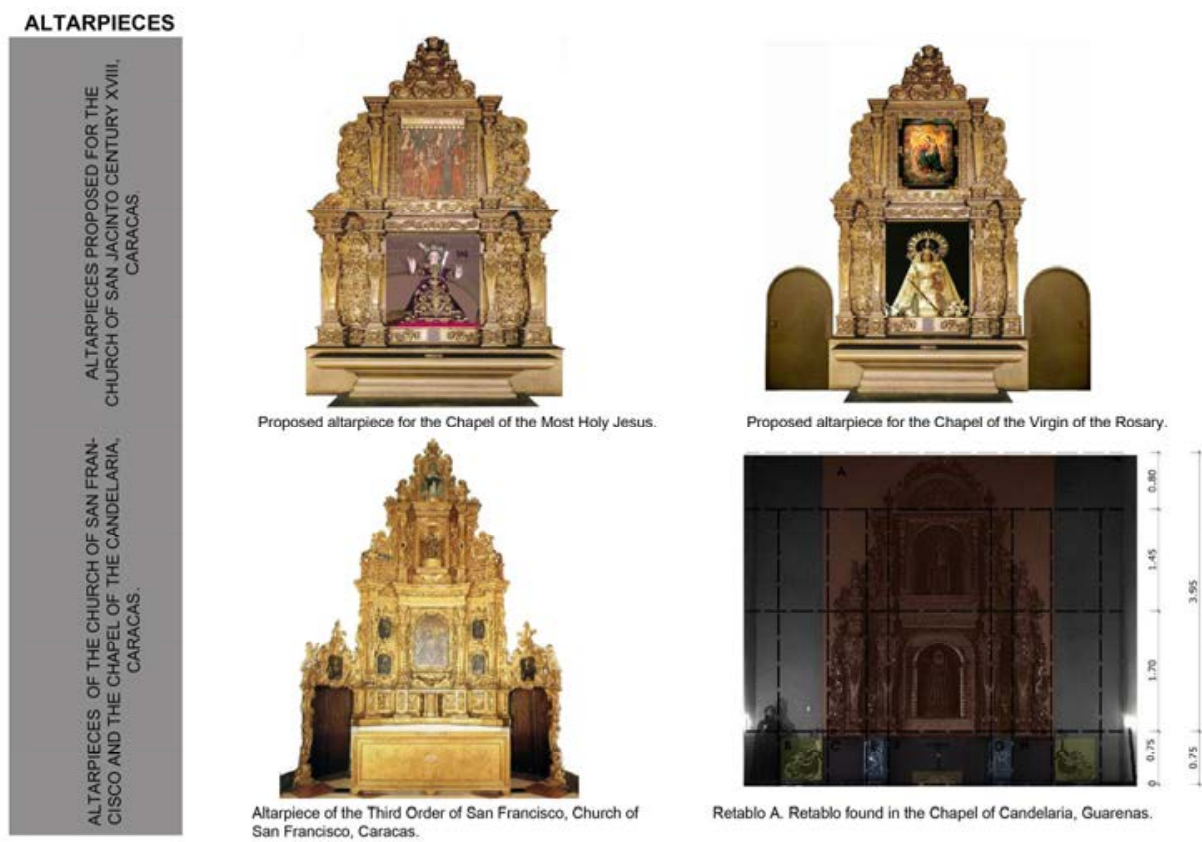

Figure 7: Altarpieces proposed for the Virtual Reconstruction of San Jacinto and Altarpiece of the Third Order of San Francisco, Caracas. (Source: own elaboration, $M D C$, 2016.) 


\section{TYPOLOGY AND ORIGINAL LOCATION}

From the virtual model of the church of San Jacinto of the XVIII century [4] and the data collected in the historical archives the following premises are proposed on typologies and probable location: there are two typologies of altarpieces, the major ones, generally of three bodies and three panels, thanks to the proportion of the presbyteries and; those of the aisles, which are generally of two bodies and one panel. The altarpiece of the Chapel of La Candelaria must have belonged to this last typology. In that sense, we know that in the interior of the Church of San Jacinto of the XVIII century there were three possible stages: the nave called "of the gospel", in whose head was the Chapel of the Holy Jesus; The nave of the epistle, with the Chapel of the Virgin of the Rosary and; The Chapel of the Nave of the Thirds, that was developed on the right side of the nave of the epistle (Fig. 8).

\section{THE DOCUMENTARY TESTIMONY}

The first description of the chapels is from the seventeenth century and is supplied by Fray Manuel de Santa María in the report sent to Governor Berroteran in 1698:

The chapel of the Holy Jesus is very well adorned with a golden altarpiece, silver pendants and hangings. The chapel of the Virgin of the Rosary, has the holy image very devout with crowns and very decent robes, it is placed in an altarpiece of neat sculpture, which is not yet finished nor golden [6].
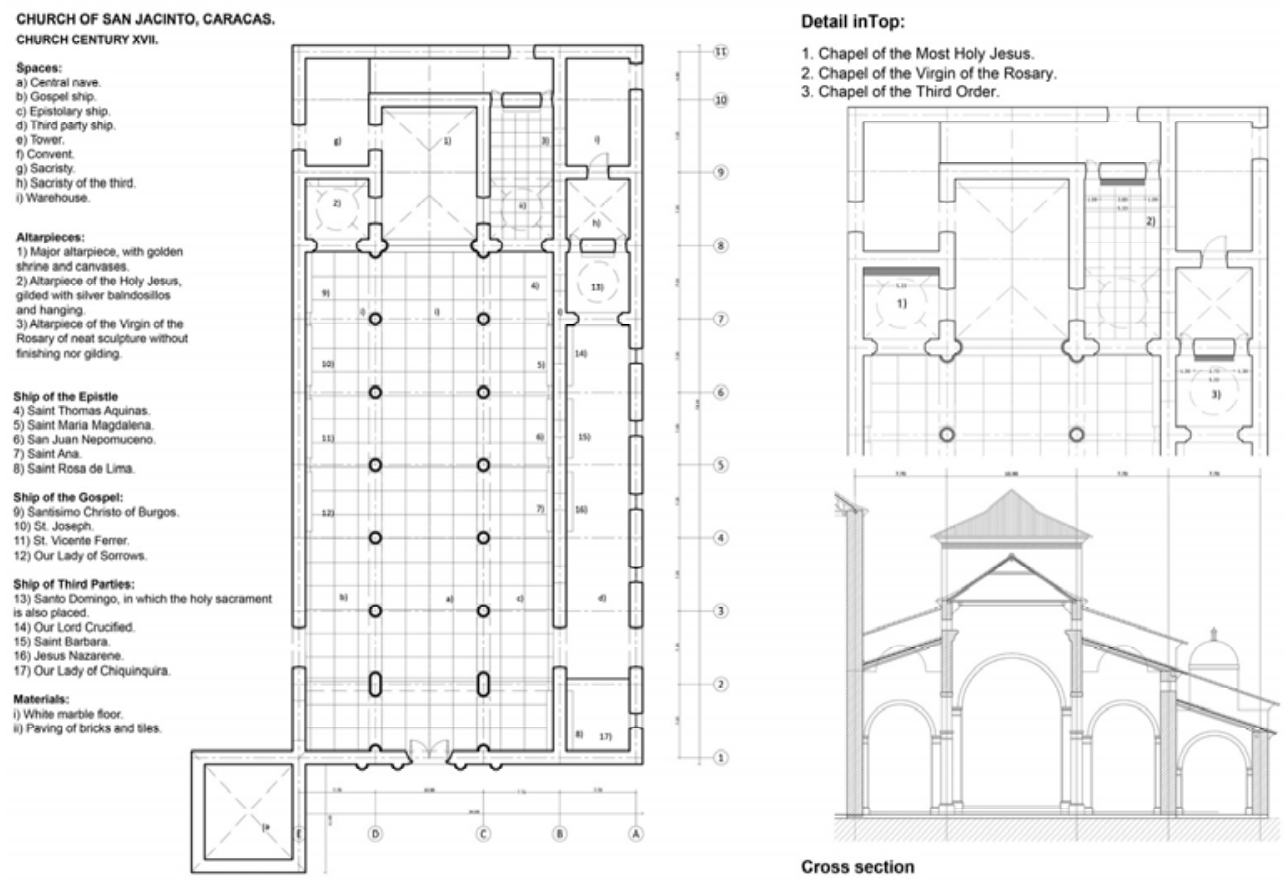

Figure 8: Church of San Jacinto according to Virtual Reconstruction. (Source: Dávila Cordido, 2011.) 
In 1701 the latter work is resumed: "Work began on what is missing from the altarpiece on January 4, 1701. Master Juan Diaz de Segovia" [7]. Fray Antonio Bueno concludes that the altarpiece had one panel, two bodies, a pedestal and a cornice, with a sculpture of the Virgin of the Rosary located in the first body and a painting of the Incarnation "... that is embedded in the altarpiece", located in the second body [6], [8]. Also the existence of two paintings is added: one of San Martín de Porras and another of the Virgin and San Jose sleeping, surely located in the lateral walls. This compositional description could be adjusted to Altarpiece A.

During the eighteenth century the altarpiece of the Virgin of the Rosary underwent modifications, so that it adapted to the fashionable conditions of the time. However, in the inventories it is not clear how its structure was. In addition, two side doors were opened, which suggests that the altarpiece had a width equal to that of the chapel.

In the middle of this century the first altarpieces with estipites appear in the capital, located in the Cathedral: of the Sacristy Major, finished by the brothers Gregorio and Juan Francisco de León Quintana in 1756, and of the Chapel of the Holy Trinity, probably realized by the same artisans towards that same time [3]. The altarpiece of the Chapel of La Candelaria of Guarenas presents stylistic characteristics very similar to this last altarpiece; the same composition with one panel, two bodies and double stands of estipites in its first body. Coincidentally, the León Quintana brothers are documentarily linked to the Church of San Jacinto for the performance of at least two altarpieces at this time: "the new Altar with the elevation to raise and lower the Holy image of Our Lady", for the Brotherhood of the Holy Rosary (1738-1740), data that has been related to the altarpiece that now exists in the parish church of San Mateo; The Tabernacle of the Church (1744) and the new altarpiece of the Chapel of the Third Order of Santo Domingo (1750) [1].

In this century the altarpiece of the Sweet Name continues to be maintained. Mariano Martí speaks of an altar and not of a Chapel. Neither does he offer an accurate description: "... in the Nave of the Gospel there are five dedicated [one] to the Holy Child Jesus, ..." [9]. Finally, in the inventory of the finished convent in 1837, we have points 1 and 10 that refer to these two chapels:

1. Altar of Our Lady of the Rosary: with its tabernacle with veil and altar for communion, corresponding sacra, its common crucifix, pallet and carpet of good use and placed - the Virgin of the Rosary.

10. Altar of the Holy Child: with its golden altarpiece, stone of ara and sacra, a crucifix, and carpet, placed - The Sweet Name of Jesus, a painting of Our Lady of the Rosary [7].

\section{CONCLUSIONS}

The conclusions are directed to the evaluation of the possible location of so-called Altarpiece A in the virtual space of the church of San Jacinto of the XVIII century, as well as the confirmation of the hypothesis of configuration of the religious space of the Church of San Jacinto de Caracas proposed in the research carried out in 2011. The rest of the pieces, by their proportions, might be part of the altarpiece of a larger nave.

Altarpiece A could belong to the Chapel of the Virgin of the Rosary, because:

- The idea that the space-altarpiece relationship leads us to define both spaces and altarpieces [4], tells us about spaces that coincide with their altarpieces and vice versa, so the altarpiece should be $5.33 \mathrm{~m}$ wide for anyone for the three space possibilities that we find. As it is not so, because the altarpiece is only $3.15 \mathrm{~m}$ wide, we have only one possible scenario: the Chapel of the Virgin of the Rosary, since it has two doors, which justify that the width of the altarpiece is smaller, to allow the passage to the sacristy and as a consequence its height must be smaller. It is necessary to take into account the proportion 
of the format of the image, close to the golden ratio. This proportion, together with its testing in perspective, in plans and sections, brings us closer to the possibility that Altarpiece A was in the Chapel of the Virgin of the Rosary in the nave of the epistle.

Fray Antonio Bueno concludes that the altarpiece completed in this chapel at the beginning of the XVIII century should have one panel, two bodies, a pedestal and a cornice, a description that is consistent with that of Altarpiece A. The brothers Gregorio and Juan Francisco de León Quintana, who introduced the estipite column in the churches of Caracas in the middle of the XVIII century - similar to those of the altarpiece of Guarenas - conclude a new altarpiece for the Chapel between 1738 and 1740 for which they had to open two side doors. The date that appears inscribed in Altarpiece A, year 1780 , indicates that the interventions had to be concluded before the suppression of the church on November 23rd, 1837.

\section{REFERENCES}

[1] Duarte, C., Grandes maestros carpinteros del período hispánico venezolano., CANTV: Caracas, pp. 116-120, 2004.

[2] Zawisza, L., Arquitectura y Obras Públicas en Venezuela, siglo XIX, Presidencia de la República: Caracas, 270 pp., 1989.

[3] Gasparini, G. \& Duarte, C., Los retablos del período hispánico en Venezuela, Armitano: Caracas, pp. 43-60, 1985.

[4] Davila Cordido, M., Estudio para la valoración y recuperación del patrimonio arquitectónico religioso Venezolano a través de técnicas digitales: iglesia de San Jacinto, caso de estudio, Universidad Politécnica de Cataluña. Escuela Superior de Arquitectura de Barcelona: Barcelona, 2011.

[5] Moronta, M., Guarenas, Litho-Mundo S.A., pp. 145-146, 1981.

[6] Bueno, A., El Convento de San Jacinto: una presencia polifacética. 500 años de Evangelización Dominicos en Venezuela, Mérida, Caracas, pp. 77-122, 1998.

[7] C. M. d. C. CMC, Libro I de cuentas de la Archicofradía del Rosario, 1687-1721. Actas del Cabildo de Caracas, I., Caracas, 105 pp., 1963.

[8] Bueno, A., Retablos del templo de San Jacinto (siglos XVII y XVIII), vol. XXV, Salamanca, 2004.

[9] Martí, M., Documentos relativos a su visita pastoral de la diócesis de Caracas. 17711784, 2nd ed., vol. 7, Academia Nacional de la Historia: Caracas, 24 pp., 1989. 